\title{
The Use of a Collegiate Software Exhibition \& Competition in Software Development Education
}

\author{
Ugochukwu Onwudebelu ${ }^{1, *}$, Godwin O. Igbinosa ${ }^{2}$, Uchenna C. Ugwoke ${ }^{3}$ \\ ${ }^{\mathbf{1}}$ Department of Computer Science, Federal University Ndufu-Alike Ikwo (FUNAI), P.M.B. 1010, Abakaliki, Ebonyi State, Nigeria \\ ${ }^{2}$ Department of Computer Science, Salem University, P.M.B. 1060, Lokoja, Kogi State \\ ${ }^{3}$ Department of Mathematics \& Computer Science, Federal University of Technology (FUT) P.M.B. 65, Minna, Niger State, Nigeria \\ *Corresponding Author: Anelectugocy@yahoo.com
}

Copyright (C) 2013 Horizon Research Publishing All rights reserved.

\begin{abstract}
A Collegiate Software Exhibition and Competition was conducted with five tertiary institutions fielding team. An in-house exhibition and competition was also carried out by one of the participating universities. These events were designed to provide student led teams with a unique opportunity and environment in which they could test and showcase their skills at software development. Teams were scored based on their ability to develop software that meets specific criteria such as technicality, marketability and user friendless amongst others. The objective of this initiative was to provide an environment where the students could exercise their information system abilities and of providing feedback to each team as its skill level and abilities was achieved over the course of these successful events. Lessons were learned which are being used to move this local event to a national level event.
\end{abstract}

Keywords Education, Competition, Software, Exhibition, Nigeria Computer Society, SIWES, Software engineering

\section{Introduction}

Employers cannot find workers with adequate skills, knowledge, and experience. As a result, companies typically blame schools, for not providing the right training and the government, for not creating the right environment for such training [4]. Although software engineering [3] education has been going on for some time in Nigeria, there are just few proficient software engineers or programmers in the country. As a result, most companies and private individuals do hunt for software as well as programmers outside the country. Part of the reasons for this unprecedented move comes from the fact that students are not given the right platform, venue, opportunities and conducive environment to showcase their hidden talents and skills. Software engineering in Nigeria is an important issue in today's environment of a ubiquitous information technology landscape. Thus, there is a need for more college graduates with significant computer programming backgrounds. Colleges turn out graduates with many different levels of specific skills related to the proper application of information technology (IT). Computer Science programs are developing the next generation of professionals that will drive our future [1]. It is very essential and paramount for college students to be involved in practical activities that would enable them to develop software that has the necessary features to solve society's need for the ever increasing technological solvable problems. As has been observed, theoretical elements are typically covered in Computer Science curriculums and very little of the technical elements, which has not proven to be sufficient to produce the desired competent programmers been sought in the IT job market and industries.

Recently, a collegiate software development exhibition and competition was conducted with participants from five tertiary institutions. Prior to this event, an in-house software development exhibition and competition was carried out in the College of Information and Communication Technology (CICT) in Salem University, Lokoja, as part of the preparation for the grand event. Both programs were designed to test students' abilities, promote excellence and built confidence in them. The discoveries made at the end of the exhibitions and competitions show some interesting revelations. The vast majority of participants stated that their curriculum did not adequately prepare them for the competition. The reasons were varied and will be discussed below.

\section{Collegiate Software Exhibition \& Competition}

Educators have confirmed that tests and other forms of evaluation such as examination, quiz or debate, helps students to discover their individual talents, promote excellence and also build self- confidence in them. However, this is against some sectional belief that examination is not the true test of one's knowledge. Exhibition and competition 
is not only about winning, as it boost cordial relationship among people, while also exposing them to learn from other people's skills and opinions. Competition is about knowledge sharing, skill acquisition, also promoting reading culture (since students will go back home having the desire to read further for the new things they have learnt), self-confidence and public speaking among the students. Competition is one of the best way to train a student on how to express himself and expose his ideas.

\subsection{In-House Salem Software Development Exhibition \& Competition}

This competition took place on Tuesday, $15^{\text {th }}$ May 2012. The venue was CICT. Four students were involved. Students from 100 Level, 200 Level and 400 Level were all encouraged to participate. 300 Level students were not involved due the fact that they were participating in industrial training scheme popularly known as SIWES (Students' Industrial Work Experience). A 4-man panel of judges evaluated the participating students, which finally involved four students two from 400 Level and the rest from 200 Level. The judges were deployed to assist in the monitoring of the event and to handle questions and issues. Although, code of dressing, skills of communication, technicality and response to questions were all used as criteria for grading, we were more or less interested in technicality, since it was the missing link between students and their proficiency in software development. At the end of the event, the final scores where $\mathrm{A}=92.5 \%, \mathrm{~B}=79.2 \%, \mathrm{C}=$ $75.6 \%$ and $\mathrm{D}=67.5 \%$. Where $\mathrm{A}$ and $\mathrm{B}$ are 400 Level students and C and D are 200 Level students. The titles for their presentations were as follow:

$\mathrm{A}=$ Online Shopping System (technicality $=55 \%$ )

$\mathrm{B}=$ Hospital Management System (technicality $=48.3 \%$ )

$\mathrm{C}=$ Design Using Ms Word (technicality $=30 \%$ )

$\mathrm{D}=$ Online Course Registration System (technicality $=20 \%$ )

Technicality determines whether the work for the project was being done with the present equipment, current procedures, existing software's technology and available personnel. Students C and D did poorly in the area of technicality because student $\mathrm{C}$ was not exhibiting a software development skills, on the contrary, he displayed his use of MS-Word tools in designing houses etc. while student D presented an uncompleted work. Students were able to learn the difference between software development and using tools in application package for designing.

\subsection{Software Development Exhibition \& Competition for Tertiary Institutions}

The Education and Manpower Development Committee (EMDC) was set up by the Nigeria Computer Society (NCS) Kogi State Chapter. It conceived the idea to conduct a collegiate software development exhibition and competition for tertiary institutions. Amongst other reasons were the desires to promote Information and Communication
Technology (ICT) in the state as well as to encourage software development practices among students. Students from tertiary institutions were also expected to collaborate with the counterpart in other places for self-development and knowledge exchange. The National Open University of Nigeria (NOUN) Study Center, Lokoja was chosen to host the event so as to provide a realistic basis for the event. Each team consisting of three students was expected to come with their own hardware and software (laptops). The reason for this decision was to allow each to display their exhibit no matter it sophistication to the full capacity. Moreover, what each intends to exhibit was not known to the judges or to EMDC. However, the students were given areas of focus which include but not limited to the following categories: education solutions (e.g. e-Campus solutions, Nigeria Lessons online solution, e-Learning - Digital Tutor solution etc); business solutions (e.g. games and entertainment solutions, graphics and virtual animation solutions, micro-banker solution etc); public sector solution (e.g. e-election solutions, climate change and Green technology solution, Nigerian Local language translator solutions etc) and web solution (e.g. e-commerce solutions, online collaboration services, virtual learning environments etc). The focus areas enable the students to proffer IT-based solutions to unique familiar problems that are peculiar to their environment.

Each team's score was a combination of how well they were able to meet the following criteria used in grading the scores [2]: (i) Concept, objectives and goals (ii) Dressing (iii) Logic e.g. flowchart, source code (iv) Use of relevant technical terms (v) Communication/presentation skill (vi) Creativity/ingenuity (vii) Documentation (viii) Marketability of software (ix) Response to questions (x) User friendliness of software. Each of these criteria carried 5 marks, giving a total of 100 marks. The final score was arrived at by finding the mean/average of the scores of the three (3) judges. The judges were deployed to each team to assist in the monitoring of the event and to handle questions and any other issues.

\section{Results of the Exhibition \& Competition}

The National Open University of Nigeria (NOUN), Lokoja Study Center hosted the exhibition and competition on Saturday, $19^{\text {th }}$ May 2012. Teams from five schools attended the event, representing the Kogi State University, Anyigba (KSU), Federal Polytechnic, Idah (FPI), Kogi State Polytechnic (KSP), Federal College of Education, Okene (FCE) and Salem University, Lokoja (SU). The participants were 400Level students from KSU and SU while the rest are a mixture of other levels from the other institutions. The only real requirement was that their institutions recognized the student competitors as full-time students. The student curriculums were a mix of computer science and information technology. At the beginning of the competition, each team 
was told to use their systems and the provided projector to showcase their product. Each team was expected to spend 20 minutes in their exhibition presentation. Therefore, they had the same time and same scoring criteria. Points were cumulative and in the end the team from SU finished in first place. Summary of the result is shown in the table 1 below. The "Integrated System" from Salem University was made up of the following subsystems: electronic shopping system, student result system, hospital management system, credit payment system and administrator page.

Table 1. Result of the Software Development Exhibition/ Competition

\begin{tabular}{|l|l|l|l|}
\hline Institution & Theme & Software Used & Score \\
\hline SU & Integrated System & $\begin{array}{l}\text { PHP \& MySql, } \\
\text { Visual Basic.net }\end{array}$ & $83.2 \%$ \\
\hline KSU & $\begin{array}{l}\text { Course Information } \\
\text { System } \\
\text { (e-Handbook) }\end{array}$ & $\begin{array}{l}\text { Java 2 Macro } \\
\text { Edition (J2ME) }\end{array}$ & $67.2 \%$ \\
\hline FCE & $\begin{array}{l}\text { Electronic Voting } \\
\text { System }\end{array}$ & Visual Basic 6.0 & 65.6 \\
\hline KSP & $\begin{array}{l}\text { Student Database } \\
\text { System }\end{array}$ & $\begin{array}{l}\text { Visual Basic } 6.0 \\
\text { \& Ms-Access }\end{array}$ & $65 \%$ \\
\hline FPI & Green Economy & PHP \& MySql, & $53.2 \%$ \\
\hline
\end{tabular}

The results of the competition were much far reaching than just crowning of the first winner. The students exchange their numbers and e-mail addresses to build and maintain the new relationship as well as improve their software development related skills and to connect to the industrial activity and leadership (judges who were working in industry as well as leaders in their various institution). Each institution went away with a critical self assessment of their strength and weaknesses and a desire to improve their performance. At the end of each of the competitions, feedback was sought from the participating students and other members present, it shows that the event was considered fair and valuable to students and sponsoring faculty members. This was an important finding as the objective was to provide a fair and realistic test-bed environment where the teams could evaluate and test their skills in a competitive environment. In all the exhibitions and competitions, the participants and audience were satisfied with the standard of the questions/ organization and commend NCS for the initiative.

\section{Benefits of the Exhibition \& Competition}

This program's goal is to promote software development education and producing a growing number of professionals with expertise in the software engineering. Software engineering is a very crucial course in the eyes of many enterprises and jobs exist in this career field. There are a number of benefits in providing a competition and an exhibition associated with software development in tertiary institution. Most problems facing the society can be solved using information technology which cannot do without software development. Unlike other aspect of IT education, software engineering has not been delivering academically prepared graduates to the workforce. One of the continuing challenges facing Nigeria society is the lack of efficient software engineers who are able to use IT tools to solve Nigeria problems.

Today's business environment is a team based endeavor, and these competition were designed to require a team based approach using student teams to achieved the result added the issues of team formation and interpersonal dynamics to the event, something the judges all got a chance to see as the hour's drew on and tempers got short. Ultimately, all of the teams achieve the true desired goal, which was to learn what they knew, what they did not and where they felt they needed to improve. Upon graduation the students were expected to be able to understand the practical aspect of the course of studies (coursework). These programs create employable students or students who can advance academically. The bottom line is to create a resource that will be in demand. Unless students can expect employability upon completion, they may lose interest in the program, after an initial surge of interest due to the novelty of the program.

Table 2. Result of the In-House Salem Software Development Exhibition \& Competition

\begin{tabular}{|c|c|c|c|c|c|}
\hline Student & Level & Theme & $\begin{array}{l}\text { Software } \\
\text { Used }\end{array}$ & $\begin{array}{c}\text { Technicality } \\
\text { Score }\end{array}$ & $\begin{array}{l}\text { Final } \\
\text { Score }\end{array}$ \\
\hline A & 400 & $\begin{array}{l}\text { Online } \\
\text { Shopping } \\
\text { System }\end{array}$ & $\begin{array}{c}\text { PHP \& } \\
\text { MySql, } \\
\text { Visual } \\
\text { Basic.net }\end{array}$ & $55 \%$ & $92.5 \%$ \\
\hline B & 400 & $\begin{array}{c}\text { Hospital } \\
\text { Management } \\
\text { System }\end{array}$ & $\begin{array}{c}\text { PHP \& } \\
\text { MySql, } \\
\text { Visual } \\
\text { Basic.net }\end{array}$ & $48.3 \%$ & $79.2 \%$ \\
\hline $\mathrm{C}$ & 200 & $\begin{array}{c}\text { Design } \\
\text { Using MS- } \\
\text { Word }\end{array}$ & MS-Word & $30 \%$ & $75.6 \%$ \\
\hline D & 200 & $\begin{array}{c}\text { Online } \\
\text { Course } \\
\text { Registration } \\
\text { System }\end{array}$ & $\begin{array}{c}\text { PHP \& } \\
\text { MySql, } \\
\text { Visual } \\
\text { Basic.net }\end{array}$ & $20 \%$ & $67.5 \%$ \\
\hline
\end{tabular}

\section{Conclusion}

This paper has sought to provide a starting point for the acquisition of practical skills in software engineering through exhibitions and competitions. Through these channels individual institutions can expand their offering, seeking to solve their region, state, and nation in the development of a future cadre of software engineering professionals. Finding ways to educate and motivate students to pursue the time consuming art of programming is not a simple task. Currently most curriculum are highly theoretical with little technicality embedded into it. These exhibitions 
and competitions were designed to breakdown that academic separation and simulate the environment the students will find themselves in after graduation. The students were exposed to the team related challenges that lie ahead of them in their future work environment. Consequently, a better and more realistic learning environment for students was built and student learnt the art of taking role in their education. Based on our success at this competition, we felt we met our initial objectives. We also felt the students were quite prepared to take this event to a national level scale.

Software development in Nigeria is still developing. The fact that we were unable to get sufficient students at each level demonstrates a general phenomenon: Apathy for software development amongst students despite the fact that the competition took place in CICT which was made up of Computer Science and Information Technology students. Moreover, the fact that no female representative were among the four students shows another red flag, that is, there is a need for female students in Nigeria to be encouraged into the art of software development. Students must be made to understand the fact that it takes determination, hard work, persistency and patient to become a marketable software developer.

The sample is a representative one because if the same exhibition and competition is carried out in another university, there is the likelihood that the same characteristics will be illustrated by students: few will be interested in hands-on software development and female representative is always low. It worth mentioning that Salem University is a private university where tuition fee is high and students are few per class and get the best attention from their lecturers, yet the trait of lacking enthusiasm in software development can be found in it. Even in the Software Development Exhibition \& Competition for Tertiary Institutions it was only one University that included a lady in their team the rest were all male. It is a general problem here in Nigeria that female representative in the universities (and in some courses and areas of specialization) is always low, though it is improving gradually and steadily.

\section{Recommendations}

a. Apart from students being expected to in a very hands-on fashion design software, it is important for them to know how to install, configure, test and maintain various technical security controls to protect their software from hackers.

b. Institutions should engage more on software exhibitions and competitions. It is very beneficial for student to attend such program since classes are predominantly lecture and students graduate without essential technical skills.

c. Universities should carry out more in-house training and competition on software development this will act as catalyze to the existent skills-gap problem since employers are relying on the schools to produce these skills for them.

d. NCS should come up with more programs that will require students to have quite specific skills, and those that will allow them have work-experience based skills.

e. NCS national should augment funding support for the competition activities.

\section{Acknowledgements}

We are very grateful Prof. Oluwade Bamidele for his coordination and directives during the competition processes.

\section{REFERENCES}

[1] Conklin Art. The use of a Collegiate Cyber Defense Competition in information Security Education, Information Security Curriculum Development (InfoSecCD) Conference'05, ACM, 16-18, 2005.

[2] Oluwade Bamidele. Report of the activities of the Education and Manpower Development Committee (EMDC) Between March 2011 and May 2012, 2012.

[3] Rayford B. Vaughn Jr., David A. Dampier, Merrill B. Warkentin, Building an Information Security Education Program. InfoSecCD Conference'04, October 8, 2004, KACM,41-45, 2005

[4] Steven Cherry. Why Bad Jobs-or No Jobs-Happen to Good Workers online available from http://spectrum.ieee.org/podcast/at-work/tech-careers/why-b ad-jobsor-no-jobshappen-to-good-workers/?utm_source=tec halert\&utm_medium $=$ email\&utm_campaign $=062112$ 